affected. Only 13 out of 76 victims were claiming compensation, and only six were considered to be suffering from appreciable post-traumatic neurosis.

No consistent relation was found between the area of burn and emotional problems after the accident. The particularly unpleasant nature of a burn injury led me to postulate that posttraumatic neurosis would be significantly more common in accident victims who sustained burns than in victims of other injuries. This was not the case. Women and men were equally affected, though more sequelae were found in men from the lower social classes. Predictive factors for a poor outcome appear to include the severity of the injury and duration of stay in hospital (both obviously linked), the presence of certain mental conditions that are identifiable in the first few days after the accident, and the presence of certain other factors including age and family size.

Maguire et $\mathrm{al}^{7}$ showed that identification of those needing psychiatric help after mastectomy led directly to psychiatric intervention and consequent reduction in psychiatric morbidity. The incidence of post-traumatic neurosis could be similarly reduced by identifying and treating patients with burn injuries who need psychiatric help.

\section{References}

${ }^{1}$ Cobb S, Lindemann E. Management of Cocoanut Grove burns at Massachusetts General Hospital. Ann Surg 1943;117:814-24.

${ }^{2}$ Adler A. Neuropsychiatric complications in victims of Boston's Cocoanut Grove disaster. FAMA 1943;123:1098-101.

${ }^{3}$ Andreason NC. Suicide attempted by self-immolation. Am $\mathcal{f}$ Psychiatry $1975 ; 132: 5$.

4 Sims M, White A, Murphy T. Aftermath neurosis: psychiatric sequelae of Birmingham bombings in victims not seriously injured. Med Sci Law 1979;19:2.

${ }^{5}$ Kennedy F. Mind of injured worker: its effect on disability neurosis. Compensation Medicine 1946;1:19.

6 Miller H. Accident neurosis. Br Med f 1961 ; i:919-25.

${ }^{7}$ Maguire R, Tait A, Brooke M, Thomas C, Sellwood R. Effect of counselling on the psychiatric morbidity associated with mastectomy. $\mathrm{Br} \mathrm{Med} \mathcal{F}$ $1980 ; 281$ : 1454-6.

(Accepted 3 November 1981)

\title{
Healing of gastric ulcers after one, two, and three months of ranitidine
}

\author{
M G ASHTON， C D HOLDSWORTH，F P RYAN， M MOORE
}

\begin{abstract}
Ranitidine (150 mg twice daily) was compared with placebo in 42 patients with gastric ulcer. The study was conducted as a double-blind trial for one month, followed by an open assessment of one, two, and three months of ranitidine in the patients with persistent ulceration.

Thirty-eight patients completed the double-blind trial. Repeat endoscopy confirmed complete healing in 16 of the 21 who had received ranitidine and five of the 17 who had received placebo $(p<0 \cdot 01)$. The remaining 17 patients with persistent ulceration participated in the open assessment. The combined cumulative healing rates of ranitidine at four, eight, and 12 weeks were $73 \%, 88 \%$, and $97 \%$. There were no adverse effects or unusual reasons for withdrawal from the study (four patients).

Ranitidine appears to be a safe and highly effective treatment of gastric ulceration, with about $90 \%$ of ulcers healed after eight weeks.
\end{abstract}

\section{Introduction}

Ranitidine is a new histamine $\mathrm{H}_{2}$-receptor antagonist whose structure and action differ considerably from those of cimetidine. ${ }^{1}$ It is more potent on a molar basis, ${ }^{23}$ and a regimen of twice-daily dosage by mouth effectively inhibits secretion of

\footnotetext{
Gastroenterology Unit, Royal Hallamshire Hospital, Sheffield S10 2JF

M G ASHTON, MB, MRCP, senior registrar

C D HOLDSWORTH, MD, FRCP, consultant physician

$M$ MOORE, SRN, RFN, research nursing officer

Department of Gastroenterology, Northern General Hospital, Sheffield S5 7AU

F P RYAN, MB, MRCP, consultant physician
}

gastric acid. ${ }^{4}$ Such a regimen may also result in healing of duodenal ulcers. ${ }^{5-9}$ As ranitidine has not been evaluated in all types of peptic ulcer, we have undertaken a study of its efficacy in gastric ulceration. The study included a double-blind trial for one month, comparing ranitidine with placebo, and an open assessment of one, two, and three months of active treatment.

\section{Patients and methods}

We selected for the trial consecutive outpatients aged 18-75 attending for endoscopy and who were found to have active, non-malignant gastric ulceration. Criteria for exclusion were: past gastric or oesophageal surgery, ulcerogenic treatment, recent perforation, pyloric stenosis, pregnancy or possible conception during the trial, breast feeding, serious concurrent systemic illness, active upper gastrointestinal haemorrhage, raised serum transaminase activities, and cimetidine within the previous four weeks.

A double-blind assessment against placebo was chosen for the first stage of the trial $(a)$ because no studies had proved the efficacy of ranitidine in gastric ulceration, and we thought it important to establish this before embarking on comparative trials with any of the drugs currently accepted as effective; and $(b)$ because a comparative trial would have been more difficult to compare with previous trials on other agents, as a healing rate with placebo in our population would not have been available for comparison with these. We also wished to have a group of patients whose ulcers had healed spontaneously to serve as controls in a double-blind trial of maintenance treatment.

The nature of the study was explained to the patients and informed, written consent obtained. Before the trial patients underwent both clinical and laboratory assessment (haematological indices; blood urea, electrolyte, and creatinine concentrations; liver function tests; and urine analysis). The patients were then given a treatment pack and instructed in its use (stage 1). Each pack contained either ranitidine $150 \mathrm{mg}$ or identical placebo to be taken twice daily, together with a supply of antacid for symptomatic relief. Allocation to a particular regimen was double-blind according to a previously randomised schedule. Any withdrawal was recorded.

The patients were reviewed after two weeks, when the laboratory investigations were repeated together with clinical assessment. They were seen again after four weeks' treatment, when a repeat endoscopy 
was performed to ascertain healing (end of stage 1). Again, clinical and laboratory investigations were repeated. If the ulcer had completely healed they were asked to take part in a long-term maintenance study (stage 3), which will be reported later. If the ulcer had not healed they were offered ranitidine, $150 \mathrm{mg}$ twice daily, on an open basis for one month after which investigations, including endoscopy were repeated (stage 2). If the ulcer still had not healed a further month of treatment was offered.

Statistical analysis of healing rates in stage 1 was undertaken by $\%^{2}$ test with Yates's correction for small numbers.

\section{Results}

Forty-two patients entered the trial; 22 were treated with ranitidine and 20 with placebo. Four patients were withdrawn from the doubleblind study. One patient was withdrawn from ranitidine treatment and one from placebo because routine biopsy showed malignancy. The remaining two patients were withdrawn while taking placebo: one patient failed to attend for his second endoscopy, and the other developed severe symptoms. Both patients entered stage 2 of the study and subsequently responded to ranitidine treatment.

In stage 1 the individual subgroups were well matched for age, sex, smoking habit, alcohol consumption, and duration of symptoms. After four weeks, 16 out of 21 gastric ulcers had healed with ranitidine, compared with five out of 17 with placebo $\left(\chi^{2}=10.31 ; p<0.01\right)$.

In stage 2 two of the five ulcers that had failed to respond to ranitidine healed after a further four weeks of treatment and the remaining three after eight weeks. After four weeks of ranitidine healing occurred in eight of the 12 ulcers that had failed to heal with placebo. Three of the four gastric ulcers which remained after one month of treatment healed after a second or third month of treatment; the fourth patient underwent surgery. Combining the blind and open studies showed that after four weeks of treatment 24 of 33 gastric ulcers $(73 \%)$ were healed by ranitidine; after eight weeks 29 of 33 $\left(88^{\circ} \%\right)$; and after 12 weeks 32 of $33(97 \%)$.

There were no clinical adverse effects associated with ranitidine, nor were there any appreciable changes in haematological and biochemical profiles.

\section{Discussion}

This study is the first to show the effectiveness of ranitidine in treatment of gastric ulcers in a placebo-controlled, double-blind study. The rate of healing was similar to that reported in duodenal ulceration, ${ }^{5-9}$ with $76 \%$ of ulcers healed at four weeks compared with $29 \%$ with placebo. This compares favourably with studies using cimetidine ${ }^{10}$ and carbenoxolone, ${ }^{11}$ though in our study the healing rate with placebo was relatively low. Once again, however, the subsequent excellent response $(66 \%$ of ulcers healed at four weeks) to open ranitidine makes bias in the original placebo group unlikely. The overalf healing rates of $73 \%, 88 \%$, and $97 \%$ at four, eight, and 12 ? weeks, respectively, again reflects the increasing efficiency ir healing with time as in duodenal ulceration. ${ }^{12}$

We found no evidence of short-term toxicity, but further ${ }^{\infty}$ long-term studies are being undertaken in most of those patiente who are being monitored in the two-year trial of maintenance treatment.

We conclude that ranitidine is superior to placebo for gastrie ulcer. Ranitidine appears to be safe and very effective, with믈 about $90 \%$ of ulcers healed after eight weeks.

\section{References}

1 Peden NR, Saunders JHB, Wormsley KG. Inhibition of pentagastrin $=$ stimulated and nocturnal gastric secretion by ranitidine, a new $\mathrm{H}_{2} \stackrel{\omega}{\mathrm{N}}$ receptor antagonist. Lancet $1979 ; \mathrm{i}: 690-2$.

- Domschke W, Lux G, Domschke S. Gastric inhibitory action of $\mathrm{H}_{2}$ antagonists, ranitidine and cimetidine. Lancet $1979 ; \mathrm{i}: 320$.

${ }^{3}$ Domschke W, Lux G, Domschke $S$. Furan $\mathrm{H}_{2}$ antagonist ranitidine in hibits pentagastrin-stimulated gastric secretion stronger than cimetidine $f$ Gastroenterology 1980;79:1267-71.

- Walt RP, Male PJ, Rawlings J, et al. 24-Hour intragastric acidity in duodenal ulcer patients on a new twice daily $\mathrm{H}_{2}$ receptor antagonist. $G$ ut $1979 ; 20$ :A904.

${ }^{5}$ Berstad A, Kett K, Aadland E, et al. Treatment of duodenal ulcer with ranitidine, a new histamine $\mathrm{H}_{2}$ receptor antagonist. Scand $\mathcal{F}$ Gastro윽 enterol 1980;15:637-9.

${ }^{6}$ Langman MJS, Henry DA, Bell DG, Burnham WR, Ogilvy A. Cimetidinev and ranitidine in duodenal ulcer. $\mathrm{Br} M e d \mathcal{F} 1980 ; 281: 473-4$.

7 Walt RP, Trotman IF, Frost R, et al. Comparison of twice daily ranitiding with standard cimetidine treatment of duodenal ulcer. Gut $1981 ; 22$ ? 323-31.

${ }^{8}$ Peden NR, Boyd EJS, Saunders JMB, Wormsley K. Ranitidine in the treatment of duodenal ulceration. Scand $\mathcal{F}$ Gastroenterol $1981 ; 16 \overrightarrow{\mathrm{e}}$ 325-9.

9 Dobrilla G, Barbara AL, Bianchi Porro G, et al. Placebo controlled studies with ranitidine in duodenal ulcer. Scand F Gastroenterol 1981;16, suppD $69: 101-5$.

${ }^{10}$ Frost F, Rahbeck I, Rune SJ, et al. Cimetidine in patients with gastrio ulcer: a multicentre controlled trial. $B r$ Med f 1977;ii:795-7.

11 Langman MJS. Carbenoxolone in the treatment of chronic gastric ulcerֶ In: Avery Jones F, ed. Peptic ulcer healing: recent studies on carbenoxolone

Lancaster: MTP Press Ltd, 1978:59-69.
12 Bardhan KD. The medical treatment of duodenal ulcer. Tropical Gastro를 enterology $1981 ; 2: 4-33$.

(Accepted 13 November 1981)
HERB TRUE-LOVE, OR ONE-BERRY. Ordinary Herb True-love has a small creeping root running under the uppermost crust of the ground, somewhat like couch grass root, but not so white, shooting forth stalks with leaves, some whereof carry no berries, the others do; every stalk smooth without joints, and blackish green, rising about half a foot high, if it bear berries, otherwise seldom so high, bearing at the top four leaves set directly one against another, in manner of a cross or ribband tied (as it is called in a true-loves knot,) which are each of them apart somewhat like unto a night-shade leaf, but somewhat broader, having sometimes three leaves, sometimes five, sometimes six, and those sometimes greater than in others, in the middle of the four leaves rise up one small slender stalk, about an inch high, bearing at the tops thereof one flower spread open like a star, consisting of four small and long narrow pointed leaves of a yellowish green colour, and four others lying between them lesser than they; in the middle whereof stands a round dark purplish button or head, compassed about with eight small yellow mealy threads with three colours, making it the more conspicuous, and lovely to behold. This button or head in the middle, when the other leaves are withered, becomes a blackish purple berry, full of juice, of the bigness of a reasonable grape, having within it many white seeds. The whole plant is without any manifest taste.

It grows in woods and copses, and sometimes in the corners or borders of fields, and waste grounds in very many places of this land, and abundantly in the woods, copses, and other places aboug Chislehurst and Maidstone in Kent. They spring up in the middle of April or May, and are in flower soon after. The berries are ripe in the end of May, and in some places in June.

Venus owns it; the leaves or berries hereof are effectual to expeI poison of all sorts, especially that of the aconites; as also, the plagues and other pestilential disorders; Matthiolus saith, that some that have lain long in a lingering sickness, and others that by witchcraft (as if was thought) were become half foolish, by taking a dram of the seeds or berries hereof in powder every day for 20 days togethefo were restored to their former health. The roots in powder taken if wine eases the pains of the cholic speedily. The leaves are very effectual as well for green wounds, as to cleanse and heal up filthy old sores and ulcers; and is very powerful to discuss all tumours an swellings in the privy parts, the groin, or in any part of the body, an\$ speedily to allay all inflammations. The juice of the leaves applied to felons, or those nails of the hands or toes that have imposthumes of sores gathered together at the roots of them, heals them in a short space. The herb is not to be described for the premises, but is fit t£ be nourished in every good woman's garden. (Nicholas Culpeper (1616-54) The Complete Herbal, 1850.) 